\title{
20. AUTHIGENIC MINERALS IN VOLCANOGENIC SEDIMENTS CORED DURING DEEP SEA DRILLING PROJECT LEG 601
}

\author{
Alain Desprairies, Université de Paris-Sud, \\ Laboratoire de Géochimie des Roches Sédimentaires, Orsay 91405, France
}

\begin{abstract}
Eocene to Pleistocene volcanogenic sediments from the Mariana Trough and the Mariana arc-trench system have been studied by X-ray diffraction, X-ray fluorescence, and atomic absorption, and with a scanning electron microscope with an X-ray-energy-dispersive attachment. The mineralogical composition of the volcaniclastic sediments (tuffs) is the same as that of the other associated sediments (mudstones). Diagenetic alterations are significant and seem to result from two processes. The first (low-temperature alteration) develops with age and depth; it consists of the genesis of pure smectite, coupled with zeolites (phillipsite, clinoptilolite). The second is limited to sediments immediately overlying basalts and to the altered basalts themselves. It consists of the massive development of palygorskite, and seems to be linked with hydrothermal activity in the igneous basement.
\end{abstract}

\section{SITE DESCRIPTION}

The following stratigraphies are summarized from the site chapters in this volume. During Leg 60 in the South Philippine Sea, four sites were drilled in the Mariana Trough (Fig. 1). Site $453\left(17^{\circ} 54.42^{\prime} \mathrm{N}-143^{\circ}\right.$ $\left.40.95^{\prime} \mathrm{E}\right)$ is about $10 \mathrm{~km}$ from the eastern edge of the West Mariana Ridge. The sediment section of lower Pliocene-upper Pleistocene, consists of $\mathbf{4 5 5 . 5}$ meters of muds and sands composed mainly of a volcanic breccia and serpentinized rock complex. Site 454 (two holes: $18^{\circ} 00.78^{\prime} \mathrm{N}-144^{\circ} 31.92^{\prime} \mathrm{E}$ ) is located in the central area of the Mariana Trough, $70 \mathrm{~km}$ east of the eastern edge of the West Mariana Ridge. There are two units: Unit I $(67 \mathrm{~m})$, which is late Pleistocene in age, is a sediment sequence composed of biogenic oozes and hemipelagic mudstones, abundant in volcanic material. Unit II $(104.50 \mathrm{~m})$ is early Pleistocene, and consists of basalt interbedded with volcanogenic sediments. Holes 456 $\left(17^{\circ} 54.68^{\prime} \mathrm{N}-145^{\circ} 10.77^{\prime} \mathrm{E}\right)$ and $456 \mathrm{~A}\left(17^{\circ} 54.71^{\prime} \mathrm{N}-145^{\circ}\right.$ $\left.10.88^{\prime} \mathrm{E}\right)$ are drilled on the eastern edge of the trough. Respectively, 34 and 114 meters of Pleistocene sediments made of vitric mudstones, sandy-silty vitric tuffs, and calcareous oozes rich with volcanic matter, were penetrated. They overlie 45 to 55 meters of basalts. Sediments from Site 455 in the Mariana Trough were not studied.

Five sites were drilled between the Mariana arc and trench. Sediments from Site 457 along the axis of the Mariana arc and from Site 458 in the fore-arc basin were not studied. Hole 459B ( $\left.17^{\circ} 51.75^{\prime} \mathrm{N}-147^{\circ} 18.09^{\prime} \mathrm{E}\right), 157$ $\mathrm{km}$ east of the axis of the active arc and $52 \mathrm{~km}$ west of the axis of the trench, is located over at the trench-slope break. 559 meters of sediments, showing many hiatuses, were recovered. They consist of: Pleistocene and early

\footnotetext{
${ }^{1}$ Initial Reports of the Deep Sea Drilling Project, Volume 60.
}

Pliocene siliceous and calcareous oozes, including many ash layers (64.50 m, Units I and II); a thick section from middle Miocene to Oligocene volcanogenic turbidites (475 m, Unit III), and early Oligocene and middle Eocene claystones and tuffs $(19.50 \mathrm{~m}$, Units IV, V, and VI). The basement basalts were drilled to 132 meters. Holes $460\left(17^{\circ} 40.14^{\prime} \mathrm{N}-147^{\circ} 35.92^{\prime} \mathrm{E}\right)$ and $460 \mathrm{~A}\left(17^{\circ}\right.$ $40.02^{\prime} \mathrm{N}-145^{\circ} 35.16^{\prime} \mathrm{E}$ ) were drilled on the arc side slope of the Mariana Trench. At Hole 460, 19 meters of Pleistocene siliceous and diatomaceous oozes overlie $57 \mathrm{me}$ ters of Oligocene-Eocene vitric calcareous oozes. At Hole 460A, 17.50 meters of identical Pleistocene sediments overlie 47.50 meters of Cenozoic-Cretaceous sediments redeposited during Pleistocene. The bottom is composed of 9.50 meters of conglomerates with pieces of igneous and metamorphic rocks. At Site $461\left(17^{\circ}\right.$ $\left.46.05^{\prime} \mathrm{N}-147^{\circ} 41^{1} .18^{\prime} \mathrm{E}\right)$ in the axis of the trench, 11 meters of reworked Quaternary siliceous muds and zeolite clays overlie 9.50 meters of igneous and sedimentary rocks conglomerate, probably representing talus.

\section{ANALYTICAL METHODS}

All samples were analyzed by X-ray diffraction. In the carbonatefree, $<2-\mu \mathrm{m}$-fraction, clay minerals were determined by various treatments of oriented aggregates (heating, glycol, hydrazine). In the particular case of smectites, the di- and trioctahedral forms (Brown, $1963)$ are classified according to the (060) lattice dimension in the powder diagrams. This method has been used by many authors (Aoki et al., 1974a; Hein and Scholl, 1977; Scheidegger and Stakes, 1977). In oriented slides, for each diffractogram the relative abundances of the principal clay minerals were estimated by the percentage of the basal peak intensities (Figs. 2 and 3) rather than by the percentage of the basal peak areas. For the other silicate minerals (zeolites, quartz, opal CT, feldspars, calcite) determined on bulk sample powder diagrams, a rough estimation, ranging from 1 to 4 , is based on one typical peak height of each mineral (Biscaye, 1965).

Various chemical analyses were carried out either on the bulk samples (major and trace elements by X-ray fluorescence and atomic absorption) or on carbonate-free $<2-\mu \mathrm{m}$ fractions (rare earth elements by neutron activation) (Tables 1 through 6). Finally, scanning electron microscope investigations and energy-dispersive analyses by $\mathrm{X}$-ray (EDAX) techniques permit semi-quantitative analyses of specific clay minerals and zeolites (Tables 7 through 9). 


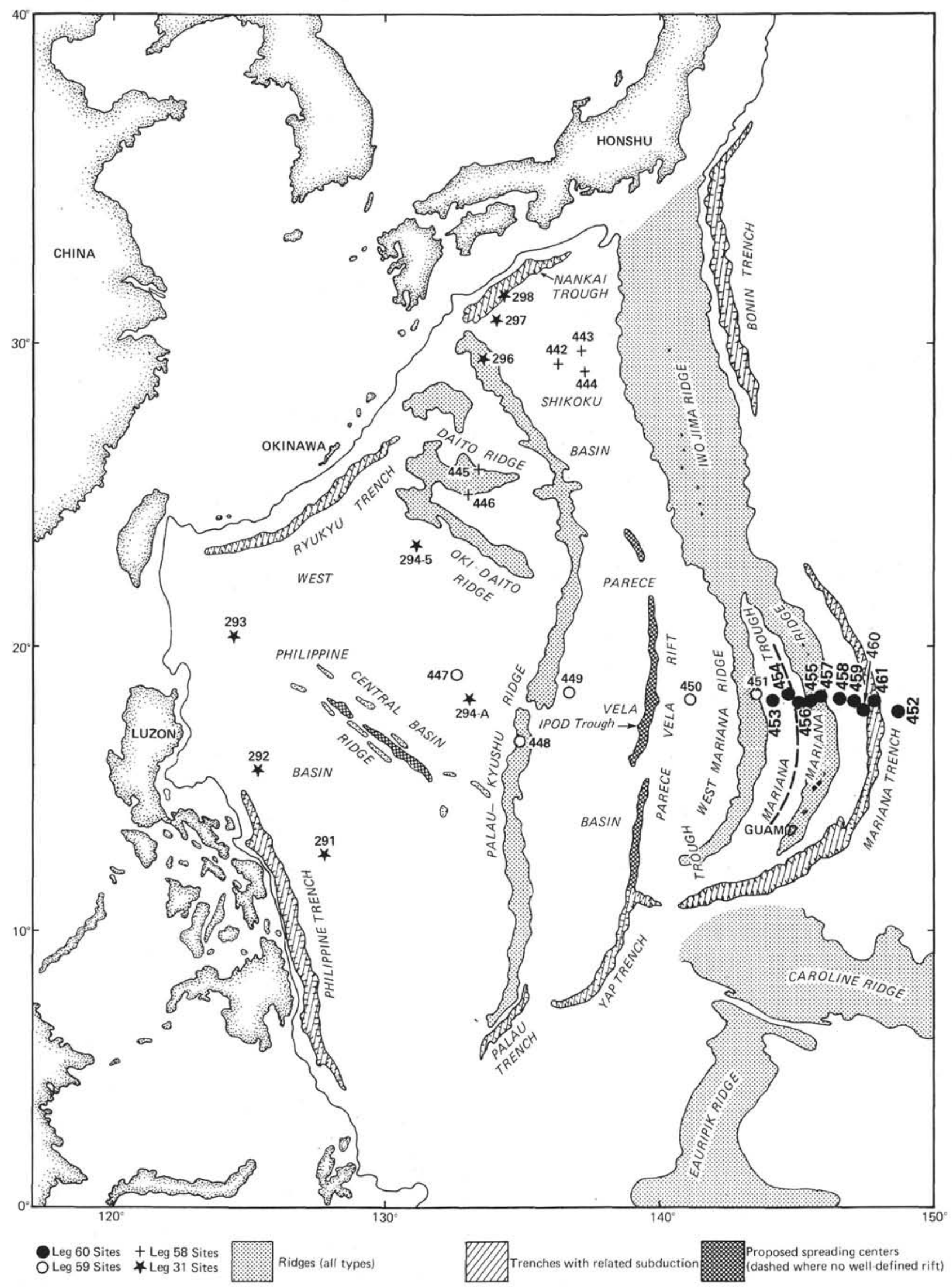

Figure 1. Location of sites drilled on Leg $60(\bullet)$ and Leg $59(0)$, Marianas-South Philippine Sea Transect. 
Table 1. Major element analyses of bulk samples, Sites $453,454,456$.

\begin{tabular}{|c|c|c|c|c|c|c|c|c|c|c|}
\hline $\begin{array}{c}\text { Sample } \\
\text { (interval in cm) }\end{array}$ & $\mathrm{SiO}_{2}$ & $\mathrm{Al}_{2} \mathrm{O}_{3}$ & $\mathrm{Fe}_{2} \mathrm{O}_{3}$ & Mno & $\mathrm{MgO}$ & $\mathrm{CaO}$ & $\mathrm{Na}_{2} \mathrm{O}$ & $\mathrm{K}_{2} \mathrm{O}$ & $\mathrm{TiO}_{2}$ & $\begin{array}{l}1 g . \\
\text { Loss }{ }^{a}\end{array}$ \\
\hline \multicolumn{11}{|l|}{ Site 453} \\
\hline $11-1,15-16$ & 61.64 & 14.73 & 6.95 & 0.222 & 3.02 & 4.77 & 2,42 & 1.05 & 0.92 & 5.77 \\
\hline $11 \cdot 1,17-18$ & 57.79 & 15.92 & 11.29 & 0.229 & 4.25 & 5.37 & 1.93 & 1.10 & 0.98 & 5.96 \\
\hline $11-1,19-20$ & 56.70 & 16.23 & 11.62 & 0.219 & 4.53 & 4.56 & 1.80 & 1.82 & 0.95 & 7.49 \\
\hline \multicolumn{11}{|l|}{ Site 454} \\
\hline $3-4,102-103$ & 52.44 & 16.23 & 12.55 & 0.245 & 4.38 & 8.99 & 2.79 & 0.26 & 1.07 & 2.18 \\
\hline $4-4,77-78$ & 52.68 & 16.03 & 12.01 & 0.209 & 4.14 & 8.50 & 2.16 & 0.92 & 1.06 & 2.18 \\
\hline \multicolumn{11}{|l|}{ Site 456} \\
\hline $4-1,26-27$ & 54.21 & 17.51 & 9.55 & 0.192 & 3.72 & 8.92 & 2.42 & 1.02 & 0.85 & 1.92 \\
\hline $4-2,28-29$ & 52.91 & 16.96 & 10.42 & 0.199 & 3.77 & 9.54 & 2.13 & 1.12 & 0.86 & 2.67 \\
\hline
\end{tabular}

${ }^{a}$ L.oss of weight (percentage) after heating to $40-1000^{\circ} \mathrm{C}$.

Table 2. Major element analyses of bulk samples, Hole 459B.

\begin{tabular}{lcccccccccc}
\hline $\begin{array}{c}\text { Sample } \\
\text { (interval in } \mathrm{cm} \text { ) }\end{array}$ & $\mathrm{SiO}_{2}$ & $\mathrm{Al}_{2} \mathrm{O}_{3}$ & $\mathrm{Fe}_{2} \mathrm{O}_{3}$ & $\mathrm{MnO}$ & $\mathrm{MgO}$ & $\mathrm{CaO}$ & $\mathrm{Na}_{2} \mathrm{O}$ & $\mathrm{K}_{2} \mathrm{O}$ & $\mathrm{TiO}_{2}$ & $\begin{array}{c}\text { Ig. } \\
\text { Los }\end{array}$ \\
\hline $27-4.23-24$ & 61.15 & 14.62 & 10.45 & 0.181 & 2.96 & 6.50 & 2.24 & 0.94 & 0.75 & 3.94 \\
$27-4,27-28$ & 56.55 & 15.91 & 11.25 & 0.198 & 3.62 & 8.65 & 2.01 & 0.63 & 0.84 & 2.05 \\
$27.4,31-32$ & 60.50 & 14.24 & 10.44 & 0.229 & 2.87 & 5.99 & 2.23 & 1.04 & 0.72 & 4.73 \\
$45-1,73-74$ & 62.07 & 15.68 & 8.43 & 0.215 & 2.94 & 4.55 & 2.06 & 2.74 & 0.76 & 5.71 \\
$45-1,75-76$ & 64.51 & 114.78 & 8.37 & 0.169 & 2.09 & 4.69 & 2.21 & 1.12 & 0.75 & 5.43 \\
$45-1,78-79$ & 59.55 & 16.73 & 9.62 & 0.210 & 3.42 & 6.43 & 2.34 & 1.00 & 0.83 & 3.50 \\
$56-3,110-111$ & 64.01 & 17.22 & 6.69 & 0.071 & 4.08 & 2.92 & 2.65 & 1.46 & 1.20 & 8.73 \\
$56-4,117-119$ & 59.16 & 16.56 & 11.09 & 1.020 & 3.43 & 3.02 & 2.52 & 2.49 & 0.66 & 8.99 \\
$57-1,120-121$ & 57.86 & 16.02 & 9.68 & 1.585 & 3.44 & 3.98 & 2.40 & 1.35 & 0.65 & 8.29 \\
$57-2,72-73$ & 59.01 & 15.96 & 10.04 & 0.820 & 4.37 & 3.87 & 1.94 & 1.68 & 0.67 & 8.50 \\
$58-1,102-103$ & 71.41 & 13.69 & 5.21 & 0.117 & 1.21 & 3.77 & 2.46 & 0.91 & 0.56 & 6.06 \\
$58-1,104-105$ & 65.68 & 14.45 & 7.44 & 0.562 & 5.02 & 2.70 & 1.28 & 1.20 & 0.58 & 10.38 \\
$59, \mathrm{CC}, 11-12$ & 56.38 & 9.73 & 9.78 & 0.807 & 13.23 & 7.01 & 1.39 & 1.64 & 1.03 & 13.33 \\
$60-1,5-7$ & 58.84 & 17.59 & 9.89 & 0.997 & 3.68 & 1.88 & 1.62 & 4.12 & 0.67 & 7.38 \\
$60-1,10-11$ & 59.50 & 17.82 & 10.35 & 0.807 & 3.84 & 1.94 & 1.58 & 3.61 & 0.65 & 8.25 \\
$65 . \mathrm{CC}$ & 55.55 & 16.60 & 11.25 & 0.136 & 4.28 & 5.33 & 2.75 & 1.43 & 1.07 & 4.13 \\
\hline & & & & & & & & & & \\
\hline
\end{tabular}

a Loss of weight (percentage) after heating to $40-1000^{\circ} \mathrm{C}$.

Table 3. Major element analyses of bulk samples, Holes 460, 460A, and 461 .

\begin{tabular}{|c|c|c|c|c|c|c|c|c|c|c|}
\hline $\begin{array}{c}\text { Sample } \\
\text { (interval in } \mathrm{cm} \text { ) }\end{array}$ & $\mathrm{SiO}_{2}$ & $\mathrm{Al}_{2} \mathrm{O}_{3}$ & $\mathrm{Fe}_{2} \mathrm{O}_{3}$ & $\mathrm{MnO}$ & $\mathrm{MgO}$ & $\mathrm{CaO}$ & $\mathrm{Na}_{2} \mathrm{O}$ & $\mathrm{K}_{2} \mathrm{O}$ & $\mathrm{TiO}_{2}$ & $\begin{array}{l}\text { I8. } \\
\text { Loss }{ }^{a}\end{array}$ \\
\hline \multicolumn{11}{|l|}{ Hole 460} \\
\hline $3-4,40-41$ & 55.23 & 13.32 & 10.36 & 0.502 & 10.85 & 3.10 & 1.51 & 1.75 & 1.03 & 8.20 \\
\hline $7-1,72-73$ & 61.76 & 14.50 & 7.81 & 1.375 & 6.66 & 1.82 & 1.34 & 2.85 & 0.61 & 10.27 \\
\hline $7=1,108-109$ & 63.56 & 13.77 & 8.83 & 1.102 & 8.49 & 1.23 & 0.98 & 2.19 & 0.78 & 11.65 \\
\hline $7, \mathrm{CC}, 5-6$ & 65.10 & 12.12 & 7.01 & 0.513 & 10.67 & 0.84 & 0.51 & 1.15 & 0.51 & 14.49 \\
\hline \multicolumn{11}{|l|}{ Hole $460 \mathrm{~A}$} \\
\hline $6-1,35-36$ & 56.07 & 10.04 & 9.94 & 0.344 & 17.35 & 2.68 & 1.09 & 1.53 & 0.78 & 9.98 \\
\hline $7-1.106-107$ & 54.54 & 11.40 & 11.41 & 0.366 & 14.59 & 2.67 & 1.35 & 1.79 & 1.01 & 8.26 \\
\hline $7 \cdot 2,7-8$ & 36.51 & 18.37 & 9.76 & 0.257 & 4.28 & 4.65 & 2.57 & 0.89 & 0.78 & 7.63 \\
\hline \multicolumn{11}{|l|}{ Hole 461} \\
\hline $2 \cdot 1,77-78$ & 59.76 & 14.89 & 10.73 & 0.485 & 6.64 & 2.61 & 1.54 & 2.89 & 1.09 & 8.37 \\
\hline $2-2,4-5$ & 58.16 & 14.89 & 10.16 & 0.604 & 8.33 & 2.40 & n.a.b & n.a. ${ }^{b}$ & 1.11 & 9.09 \\
\hline
\end{tabular}

\section{RESULTS}

\section{Mineralogical Patterns}

In the Mariana Trough and the arc-trench system, two types of sedimentation have been described (see site chapters, this volume): "basin" sedimentation represented by bioturbated layers of hemipelagic muds and oozes, and "arc-derived" sedimentation, in which sediments are mainly volcaniclastic. In this instance, the sediments are made of graded and non-burrowed silty or sandy tuffs that bear the characteristics of turbidites. The analyzed samples correspond to these two types of sediments.

\section{Sites 453, 454, and 456 (Fig. 2)}

The early Pliocene-late Pleistocene sediments have a remarkably uniform mineralogical pattern which seems
Table 4. Trace element analyses (ppm) of bulk samples, Hole 459B.

\begin{tabular}{lcrrrrrrr}
\hline $\begin{array}{c}\text { Sample } \\
\text { (interval in cm) }\end{array}$ & $\mathrm{V}$ & $\mathrm{Cr}$ & $\mathrm{Co}$ & $\mathrm{Ni}$ & $\mathrm{Cu}$ & $\mathrm{Zn}$ & $\mathrm{Li}$ & $\mathrm{Sr}$ \\
\hline $27-4,23-24$ & 202 & 7 & 42 & 30 & 133 & 187 & 19 & 275 \\
$27-4,27-28$ & 281 & 6 & 49 & 38 & 122 & 143 & 14 & 266 \\
$27-4,31-32$ & 169 & 3 & 47 & 47 & 131 & 250 & 22 & 336 \\
$45-1,73-74$ & 165 & 13 & 34 & 30 & 109 & 190 & 30 & 208 \\
$45-1,75-76$ & 105 & 2 & 38 & 30 & 82 & 102 & 15 & 202 \\
$45-1,78-79$ & 247 & 12 & 44 & 38 & 142 & 178 & 22 & 210 \\
$56-3,110-111$ & 687 & 113 & 187 & 363 & 225 & 219 & 67 & 170 \\
$56-4,117-119$ & 200 & 22 & 110 & 195 & 312 & 305 & 46 & 259 \\
$57-1,120-121$ & 139 & 69 & 61 & 61 & 130 & 167 & 51 & 241 \\
$57-2,72-73$ & 72 & 52 & 87 & 185 & 269 & 162 & 70 & 283 \\
$58-1,102-103$ & n.d. & 19 & 38 & 46 & 49 & 193 & 24 & 176 \\
$58-1,104-105$ & 63 & 38 & 61 & 97 & 204 & 281 & 121 & 164 \\
$59, C C, 11-12$ & 113 & 192 & 91 & 388 & 155 & 241 & 70 & 206 \\
$60-1,5-7$ & 107 & 24 & 60 & 119 & 116 & 191 & 50 & 229 \\
$60-1,10-11$ & 139 & 39 & 71 & 132 & 142 & 139 & 51 & 272 \\
$65, C C$ & 412 & 5 & 45 & 41 & 68 & 96 & 15 & 142 \\
\hline
\end{tabular}

$\mathrm{a}_{\text {n.d. }}=$ not detected.

Table 5. Trace element analyses (ppm) of bulk samples, Holes 460 , $460 \mathrm{~A}$, and 461 .

Sample

$\begin{array}{lllllllll}\text { (interval in } \mathrm{cm} \text { ) } & \mathrm{V} & \mathrm{Cr} & \mathrm{Co} & \mathrm{Ni} & \mathrm{Cu} & \mathrm{Zn} & \mathrm{Li} & \mathrm{Sr}\end{array}$

Hole 460

\begin{tabular}{lrrrrrrrr}
$3-4,40-41$ & 135 & 267 & 65 & 236 & 173 & 214 & 39 & 177 \\
$7-1,72-73$ & 139 & 111 & 100 & 249 & 196 & 203 & 52 & 189 \\
$7-1,108-109$ & 157 & 148 & 75 & 167 & 170 & 372 & 55 & 132 \\
$\begin{array}{c}\text { Hole } 460 \text { A } \\
\text {-1, 35-36 }\end{array}$ & 143 & 478 & 62 & 395 & 187 & 167 & 33 & 112 \\
$\begin{array}{c}7-2,7-8 \\
\text { Hole } 461\end{array}$ & 171 & 23 & 69 & 95 & 142 & 114 & 62 & 348 \\
$2-2,4-5$ & 179 & 290 & 112 & 283 & 388 & 308 & 62 & 175 \\
\hline
\end{tabular}

Table 6. REE contents (ppm) in the $<2-\mu \mathrm{m}$ clay size fraction of selected samples (see Fig. 4).

\begin{tabular}{lccccccccr}
\hline $\begin{array}{c}\text { Sample } \\
\text { (interval in cm) }\end{array}$ & $\mathrm{La}$ & $\mathrm{Ce}$ & $\mathrm{Nd}$ & $\mathrm{Sm}$ & $\mathrm{Eu}$ & $\mathrm{Tb}$ & $\mathrm{Yb}$ & $\mathrm{Lu}$ & Total \\
\hline $459 \mathrm{~B}-56-3,110-111$ & 9.05 & 14.1 & 9.5 & 1.90 & 0.54 & 0.42 & 1.50 & 0.33 & 37 \\
$459 \mathrm{~B}-56-4,117-119$ & 87.1 & 76.3 & 95.4 & 19.9 & 5.56 & 4.2 & 12.2 & 2.01 & 302 \\
$459 \mathrm{~B}-59, \mathrm{CC}, 11-12$ & 11.4 & 25.9 & 12.6 & 2.7 & 0.65 & 0.50 & 1.25 & 0.25 & 55 \\
$460-7-1,108-109$ & 33.6 & 45.9 & 36.3 & 8.09 & 1.95 & 1.80 & 5.79 & 1.12 & 135 \\
\hline
\end{tabular}

to be independent of the type of sedimentation ("basin" or "'arc-derived"). Zeolites, quartz, opal CT are nearly absent; feldspars (An 50-70) and pyroxenes are abundant; calcite is to be found only in late Pleistocene of Sites 454 and 456 . Clay minerals are equally divided between di- and trioctahedral smectites, mixed layer clays (illite-smectite and chlorite-smectite), chlorite and illite. Talc is common. The clay fraction in the sediments is very small compared to the sandy or silty fraction, in addition to which the clay minerals are very poorly crystallized.

Holes 459B, 460, 460A, and 461 (Figs. 2 and 3)

If we consider all the Pleistocene-late Quaternary sediments from Holes $460 \mathrm{~A}$ and 461 and if we compare 
Table 7. X-ray energy dispersive semi-quantitative analyses of clay minerals from selected samples.

\begin{tabular}{llccccccccc}
\hline $\begin{array}{c}\text { Sample } \\
\text { (interval in cm) }\end{array}$ & Specimen & $\mathrm{SiO}_{2}$ & $\mathrm{Al}_{2} \mathrm{O}_{3}$ & $\mathrm{Fe}_{2} \mathrm{O}_{3}$ & $\mathrm{MnO}$ & $\mathrm{MgO}$ & $\mathrm{CaO}$ & $\mathrm{Na}_{2} \mathrm{O}$ & $\mathrm{K}_{2} \mathrm{O}$ & $\mathrm{TiO}_{2}$ \\
\hline Hole 459B & & & & & & & & & & \\
$56-3,110-111$ & Beidellite & 64 & 17 & 8 & - & 4 & 2 & 2 & 2 & 1 \\
$56-4,117-119$ & Iron-Beidellite & 57 & 16 & 13 & 3 & 3 & 2 & 4 & 1 & 1 \\
$60-1,10-11$ & 59 & 19 & 13 & - & 2 & 1 & 1 & 5 & - \\
$59, \mathrm{CC}, 11-12$ & Serpentine & 52 & - & 6 & 1 & 4 & - & - & - & - \\
Hole 460A & & & & & & & & & & \\
$6-1,35-36$ & Tale-Saponite & 59 & 4 & 7 & - & 29 & 1 & - & 1 & - \\
$6-1,35-36$ & Iron-Saponite & 58 & 11 & 9 & 1 & 16 & 1 & 1 & 2 & 1 \\
Hole 460 & & & & & & & & & & \\
$7, \mathrm{CC}, 5-6$ & Palygorskite & 69 & 13 & 5 & - & 11 & 1 & - & 1 & - \\
\hline
\end{tabular}

Note: Relative error $= \pm 5 \%$ on $50 \%$ oxide; $\pm 10 \%$ on $5-10 \% ; \pm 20 \%$ on $5 \%$.

Table 8. Structural formulae of clay minerals derived from the analyses of Table 7.

\begin{tabular}{|c|c|c|}
\hline $\begin{array}{c}\text { Sample } \\
\text { (interval in } \mathrm{cm} \text { ) }\end{array}$ & Specimen & \\
\hline \multicolumn{3}{|l|}{ Hole 459B } \\
\hline $56-3,110-111$ & Beidellite & $\left(\mathrm{Si}_{3.90} \mathrm{Al}_{0.10}\right)\left(\mathrm{Al}_{1.14} \mathrm{Fe}^{3}{ }_{3}{ }_{3} 7 \mathrm{Mg}_{0.37}{ }_{3} \mathrm{Ti}_{0.06}\right) \mathrm{Na}_{0.27} \mathrm{~K}_{0.13} \mathrm{Ca}_{0.10} \mathrm{O}_{10}\left(\mathrm{OH}_{2}\right.$ \\
\hline $56-4,117-119$ & Iron-Beidellite & $\left(\mathrm{Si}_{3} .66 \mathrm{Al}_{0.34}\right)\left(\mathrm{Al}_{0.84} \mathrm{Fe}^{3} .{ }_{65}^{+} \mathrm{Mg}_{0.32} \mathrm{Mn}_{0.14}^{2}{ }_{14} \mathrm{Ti}_{0.02}\right) \mathrm{Na}_{0.46} \mathrm{Ca}_{0.14} \mathrm{~K}_{0.12} \mathrm{O}_{10}(\mathrm{OH})_{2}$ \\
\hline $60-1,10-11$ & & $\left(\mathrm{Si}_{3.73} \mathrm{Al}_{0.27}\right)\left(\mathrm{Al}_{1.13} \mathrm{Fe}_{0.62}^{3}{ }_{62} \mathrm{Mg}_{0.19}\right) \mathrm{K}_{0.43} \mathrm{Na}_{0.15} \mathrm{Ca}_{0.02} \mathrm{O}_{10}(\mathrm{OH})_{2}$ \\
\hline $59, \mathrm{CC}, 11-12$ & Serpentine & $\mathrm{Si}_{2.12}\left(\mathrm{Mg}_{2.43} \mathrm{Fe}_{0.19}^{3}{ }_{19}^{-} \mathrm{Mn}_{0.03}^{2}\right)_{5}(\mathrm{OH})_{4}$ \\
\hline \multicolumn{3}{|l|}{ Hole $460 \mathrm{~A}$} \\
\hline $6-1,35-36$ & Talc-Saponite & $\left(\mathrm{Si}_{3.68} \mathrm{Al}_{0.26} \mathrm{Fe}^{3} .066\right)\left(\mathrm{Mg}_{2.64} \mathrm{Fe}_{0}^{3} .{ }_{24}\right) \mathrm{Mg}_{0.08} \mathrm{Ca}_{0.06} \mathrm{~K}_{0.01} \mathrm{O}_{10}(\mathrm{OH})_{2}$ \\
\hline $6-1,35-36$ & Iron-Saponite & $\left(\mathrm{Si}_{3.67} \mathrm{Al}_{0.33}\right)\left(\mathrm{Mg}_{1.51} \mathrm{Al}_{0.47} \mathrm{Fe}_{0.42}^{3}{ }^{+} \mathrm{Mn}_{0.01}^{2}{ }_{01}^{+} \mathrm{Ti}_{0.04}\right) \mathrm{K}_{0.15} \mathrm{Ca}_{0.11} \mathrm{Na}_{0.10} \mathrm{O}_{10}\left(\mathrm{OH}_{2}\right.$ \\
\hline \multicolumn{3}{|l|}{ Hole 460} \\
\hline $7, \mathrm{CC}, 5-6$ & Attapulgite & $\left(\mathrm{Si}_{7.87} \mathrm{Al}_{0.13}\right)\left(\mathrm{Al}_{1.38} \mathrm{Fe}_{0.49}^{3}{ }_{4}^{+} \mathrm{Mg}_{1.87}\right) \mathrm{K}_{0.14} \mathrm{Ca}_{0.02} \mathrm{O}_{20}(\mathrm{OH})_{2}\left(\mathrm{OH}_{2}\right)_{4}$ \\
\hline
\end{tabular}

Table 9. X-ray-energy-dispersive semi-quantitative analyses of zeolites and $\mathrm{K}$-feldspars from selected samples.

\begin{tabular}{l|ccccccc}
\hline $\begin{array}{c}\text { Sample } \\
\text { (interval in cm) }\end{array}$ & Specimen & $\mathrm{SiO}_{2}$ & $\mathrm{Al}_{2} \mathrm{O}_{3}$ & $\mathrm{Fe}_{2} \mathrm{O}_{3}$ & $\mathrm{CaO}$ & $\mathrm{Na}_{2} \mathrm{O}$ & $\mathrm{K}_{2} \mathrm{O}$ \\
\hline $41, \mathrm{CC}, 6-7$ & & 68 & 18 & 1 & 1 & 3 & 9 \\
$56-4,3-4$ & Phillipsite & 68 & 20 & 2 & 1 & 6 & 3 \\
$56-4,117-119$ & & 65 & 20 & 1 & 1 & 6 & 7 \\
\hline \multirow{5}{*}{$59, \mathrm{CC}, 11-12$} & & 69 & 20 & - & 1 & 5 & 5 \\
\hline & & 79 & 14 & - & 6 & - & 1 \\
& Clinoptilolite & 82 & 13 & - & 4 & - & 1 \\
\cline { 2 - 8 } & & 82 & 12 & - & 5 & - & 1 \\
\hline
\end{tabular}

Note: Relative error as for Table 7.

them to those of the same period in the Mariana Trough, we see that:

The silicate mineralogy is much more homogeneous than would appear from the differences in the lithology of the various sediments;

The smectites are better crystallized and also in greater amount, whereas the mixed layers decrease in percentage; the chlorite/illite ratio is very irregular;

Some palygorskite and, especially, some serpentine minerals are present; and

The calcite content is low, but opal CT, quartz, and phillipsite are well represented.

We may thus say that the sediments are less of the detrital type than in the Mariana Trough. But one must not forget that for the main part they are redeposited from older sediments which were found in situ in Holes 459B and 460.
The middle to late Miocene volcaniclastic turbidites of Hole 459B were superimposed on a calcareous biogenic sedimentation, which attests to a quieter tectonic regime than in the Mariana Trough. Their mineralogy is identical to that of the Pleistocene turbidites of the trough provided we do not take into consideration the presence of biogenic silica or carbonates. From bottom to top of the same turbidite sequence, despite structural and grain-size changes (from graded tuffs to the vitric mudstones), there are no changes in the mineralogical distributions. When there are changes, as for example the disappearance of mixed-layer clays, they exist in the whole sequence. On the whole, the percentage of smectites and mixed-layer clays is higher in the Miocene sediments than in Pleistocene sediments.

In the late Oligocene, the gray-green volcaniclastic turbidites are superseded by partly diagenetic brownish claystones: smectites are well developed and crystallized; the percentage of mixed layers and chlorite decreases; talc disappears; biogenic silica (opal CT and quartz) and zeolites are common.

During the early Oligocene and middle Eocene, volcaniclastic turbidites were abundant, intercalated with brownish claystones. In each facies we find the same mineralogical pattern mentioned above in Miocene and late Oligocene sediments, with two important mineralogical additions: the presence of serpentine in Hole 459B (as well as in Hole 460) and the mass development of palygorskite in the sediments immediately above the basalts. It is to be noted that in Hole 460A these two minerals are present in the Pleistocene sediments which 

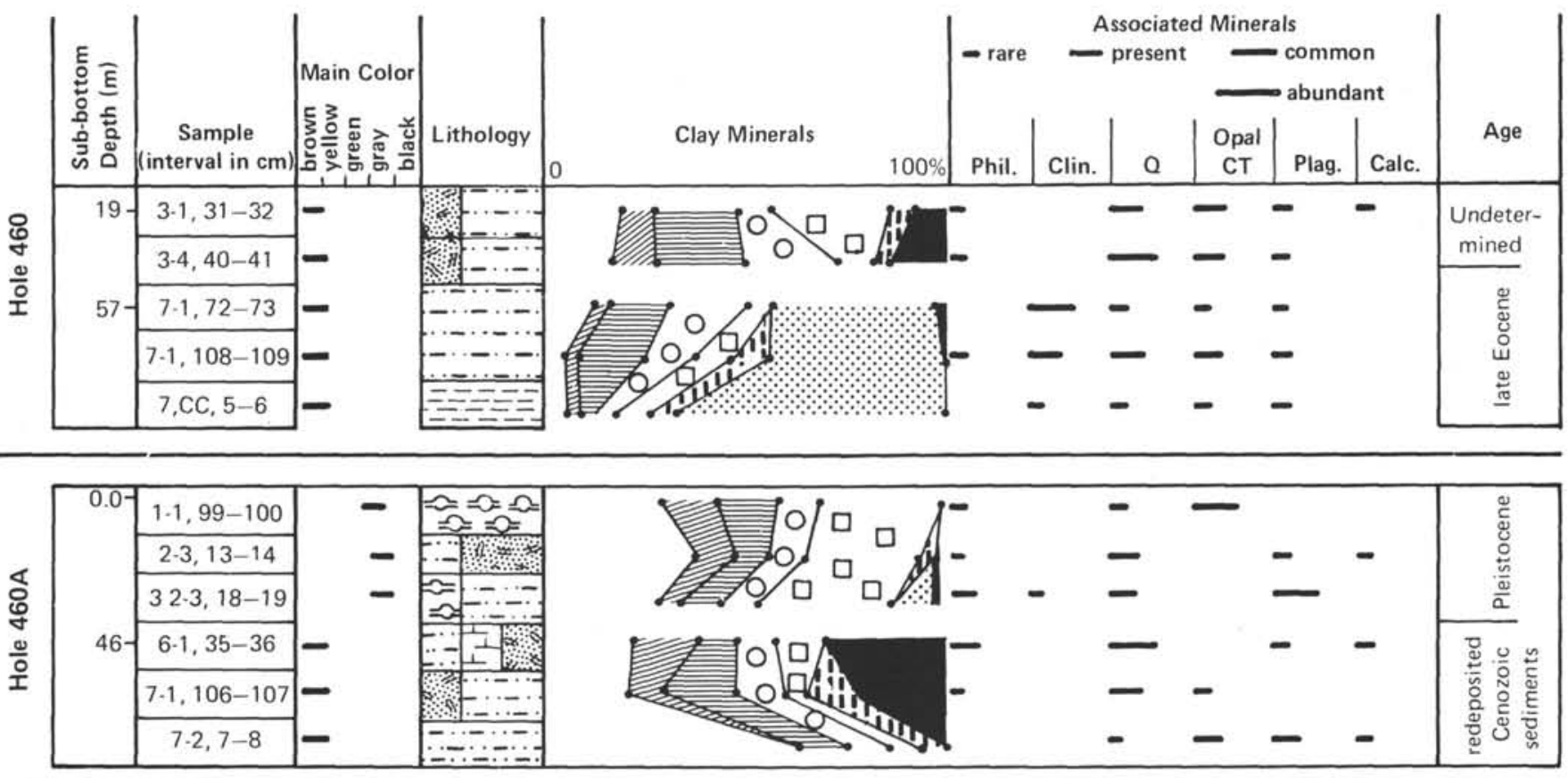

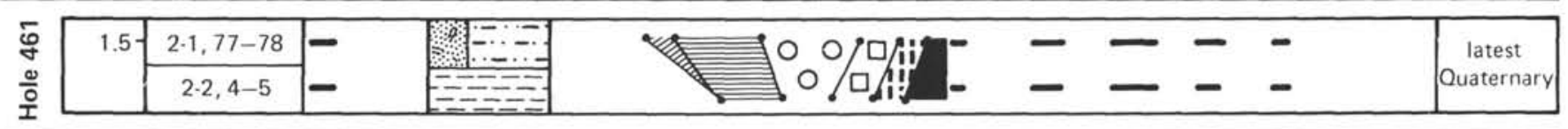
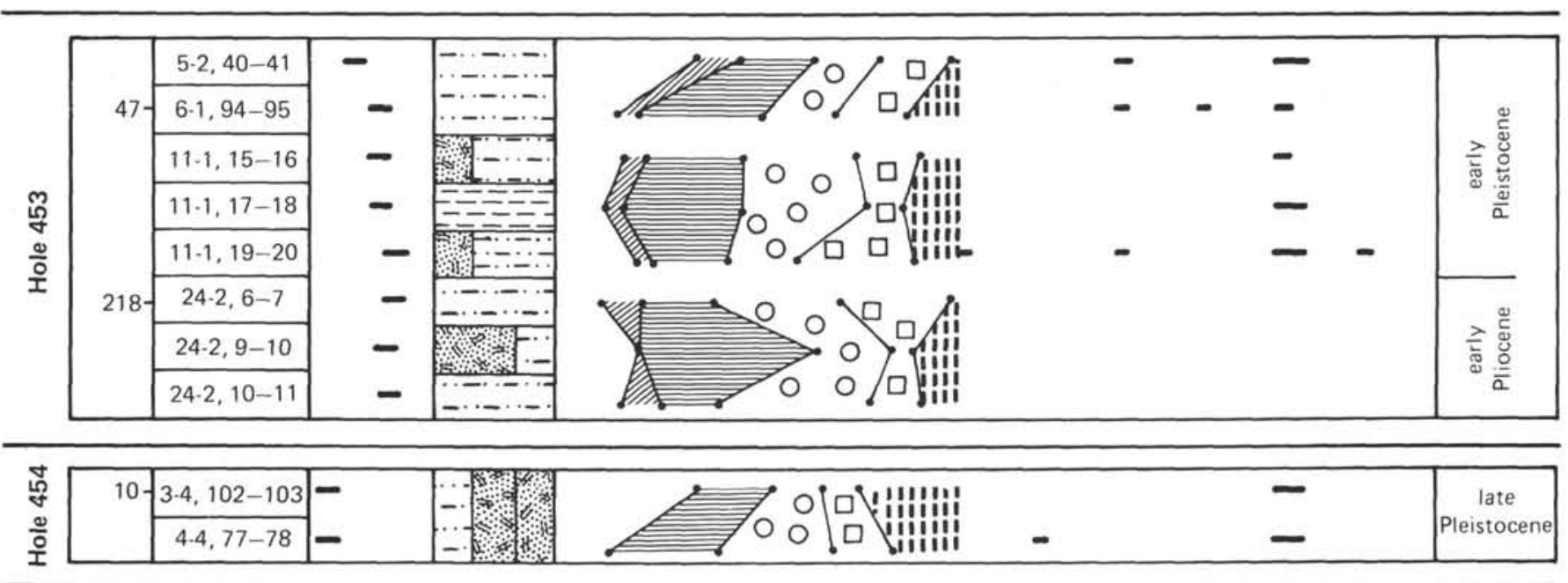



\begin{tabular}{|c|c|c|c|}
\hline dioctahedral smectites & trioctahedral smectites & mixed layers & 00 \\
\hline 望消 taic & attapulgite & serpentine & $\square \square$ \\
\hline
\end{tabular}

Figure 2. Mineralogical pattern of sediments at Holes 453, 454, 456, and 456A (Mariana Trough) and at Holes 460, 460A, and 461 (Mariana Trench). 


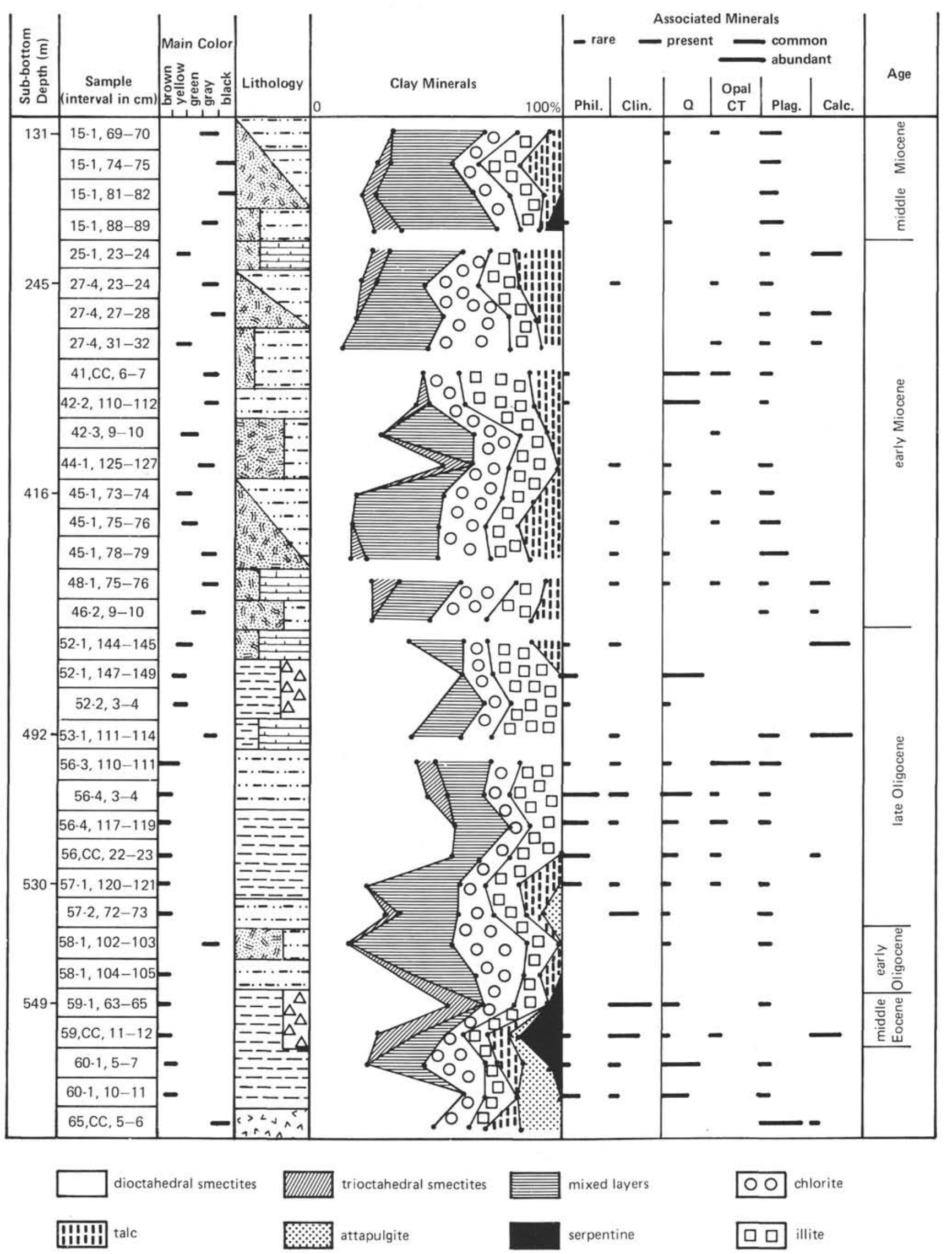

Figure 3. Mineralogical pattern of sediments at Hole 459B (Mariana Trench). 
contain some reworked Cenozoic elements (see site chapter, this volume).

\section{Chemical Composition of the Sediments}

\section{Major Elements}

The irregular occurrence of magnesium in some sediments is directly related to the content of specific minerals, namely detrital (serpentine) or authigenic (palygorskite) (Tables 1 through 3 ). In order to see the possible influence of submarine weathering on active ridges as a partial source of iron and manganese, we have examined a graph plotting $\mathrm{Fe} / \mathrm{Ti}$ versus $\mathrm{Al}(\mathrm{Al}+\mathrm{Fe}$ $+\mathrm{Mn}$ ), by Boström et al. (1972). All the sediments show a negligible mixture of "ridge" components (5$10 \%$ of "typical" active ridge sediment containing $22 \%$ $\mathrm{Fe}, 8.8 \% \mathrm{Mn}, 0.5 \% \mathrm{Al}$, and $0.02 \% \mathrm{Ti}$ ) with material the composition of which is near that of the average continental crust $(5.4 \% \mathrm{Fe}, 0.095 \% \mathrm{Mn}, 8.3 \% \mathrm{Al}$, and $0.52 \% \mathrm{Ti})$.

\section{Trace Elements}

The occurrence of serpentine in some sediments is confirmed by a high $\mathrm{Cr} / \mathrm{Ni}$ ratio. Elsewhere, at Hole 459B, the REE patterns and the behavior of chromium versus vanadium are the most significant indicators of compositional variations showing the origin and nature of volcaniclastic products.

In Miocene sediments, the average of $\mathrm{Cr}(7 \mathrm{ppm})$ and $\mathrm{V}(195 \mathrm{ppm})$ is comparable with the average of these elements (50 and $313 \mathrm{ppm}$, respectively) in recent lavas from five volcanically active islands in the northern Marianas (Dixon and Batiza, 1979). These lavas have both characteristics of "island arc tholeiitic series"' and "calc-alkaline" suites. A plot of $\mathrm{Cr}$ versus V (Miyashiro and Shido, 1975) in the volcanogenic sediments corroborates this geochemical trend.

From late Oligocene to middle Eocene, the volcanogenic sediments had a more calc-alkaline composition. This is proved on the one hand by the plot of $\mathrm{Cr}$ versus $\mathrm{V}$ (average $\mathrm{Cr}=60 ; \mathrm{V}=190$ ), and on the other hand by enrichment in light REE abundances (Fig. 4) with a high $\mathrm{La} / \mathrm{Yb}$ ratio (6-9), such as occurs in calc-alkaline rocks of island arcs (Jakeŝ and White, 1972). This calc-alkaline trend is also found in Eocene sediments of the Mariana Trench, Hole 460A.

\section{Chemical Composition of Minerals}

\section{Zeolites}

There is no phillipsite in the gray-green tuffs, but this mineral is very abundant in brown claystones which have a high proportion of iron-smectites (Hole 459B, late Oligocene). They are siliceous ( $\mathrm{Si} / \mathrm{Al}$ near to 3; Kastner and Stonecipher, 1978) with $\mathrm{Na}$ and $\mathrm{K}$ in nearly equal proportions higher than $\mathrm{Ca}$ (Table 9). Numerous features of dissolution can be seen on the surfaces of these minerals (Plate 1). Clinoptilolite ( $\mathrm{Si} / \mathrm{Al}$ near to 5-6; Boles, 1971) is especially abundant in the brown siliceous claystones of middle Eocene age (Plate 1) and is associated with clay minerals rich in $\mathrm{Fe}$ and $\mathrm{Mg}$

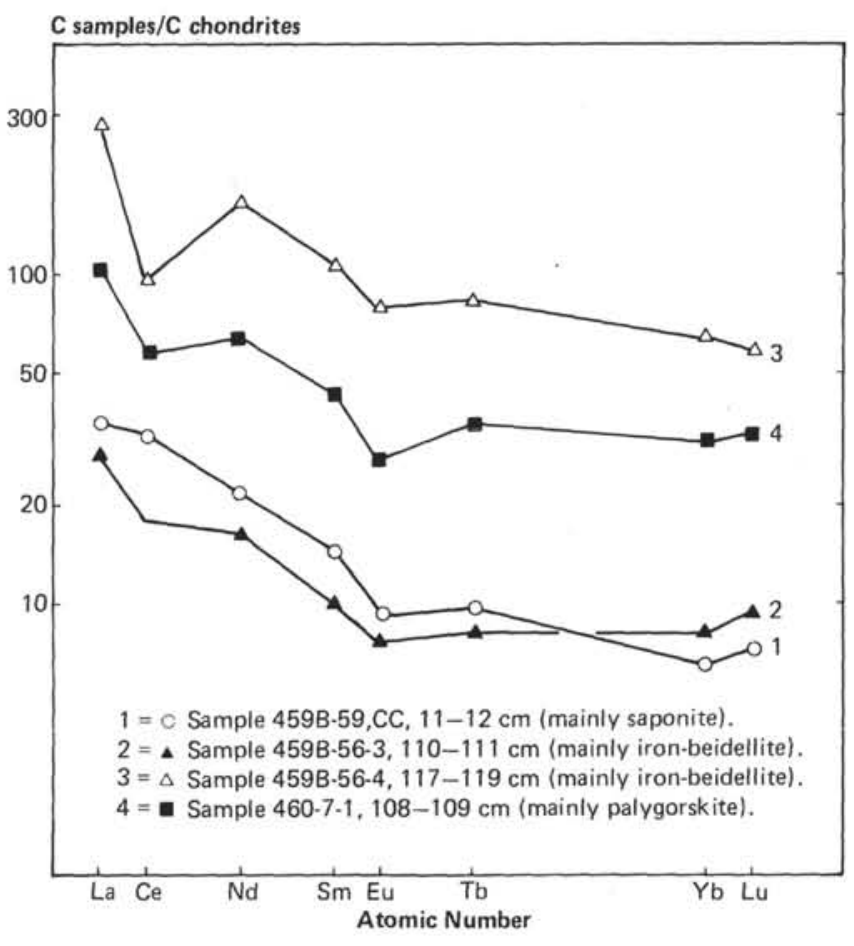

Figure 4. Chondritic normalized pattern of REE for the $<2-\mu \mathrm{m}$ fraction (carbonate-free) of selected samples, Holes 459B and 460 .

(serpentine, talc, palygorskite, saponite). Its abundance is inverse to that of phillipsite from which it could be derived by diagenesis. This is corroborated by the fact that clinoptilolite contains only calcium and that in one sample (Sample 459B-59,CC, 11-12 cm) it was found associated with a K-feldspar (Table 9).

\section{Opal and Quartz}

These minerals are to be found together in mudstones and claystones, except in the silicified layers when quartz is to be found alone. Generally speaking, opal $\mathrm{CT}$ is more common in phillipsite layers than in clinoptilolite layers where quartz is more frequent.

\section{Serpentine}

It occurs usually in fibrous fragments dispersed in the sediments. It contains some iron in octahedral coordination (Tables 7 and 8).

\section{Trioctahedral Smectites}

These are also iron-rich and more or less aluminous (Weaver and Pollard, 1973). We distinguished (1) saponites sensu stricto (Tables 7 and 8). These are very similar to saponite-talc mixed layers (Alietti, 1959); with the SEM they are disclosed as more or less fragmented laths (Plate 2), which can easily be mistaken for palygorskite or serpentines (Beutelspacher and van der Marels, 1968). (2) Iron saponites. These are more frequent than saponite sensu stricto, and have been described more often in the literature (Kohyama et al., 1973; Melson and Thompson, 1973; Scheidegger and Stakes, 1977). Their abundance is inversely proportional to that of talc. The rare-earth element distribution was studied in 
one sample, the clay fraction of which is mainly composed of saponite (Sample 459B-59,CC, 11-12 cm) (Fig. 4). The chondritic normalized pattern is slightly enriched in light REE and does not show any cerium depletion. A negative cerium anomaly has often been found in authigenic products (Piper, 1974) such as phillipsite and nontronite. But, the absence of such depletion does not prove a detrital origin at all, especially for saponites (Fleet et al., 1976).

\section{Dioctahedral Smectites}

These are more or less ferric or aluminous and always have some magnesium in octahedral positions (Aoki, 1974a). They consist of two types:

Beidellites, which contain a high proportion of interlayer potassium (Tables 7 and 8), may be compared to illite-smectite mixed-layer clays, but the proportion of illite layers is much less (Reynolds and Hower, 1970).

Other beidellites contain mostly $\mathrm{Na}$ and $\mathrm{Ca}$ in interlayer positions (Tables 7 and 8). Their crystallinity improves as the substitution of octahedral aluminum by iron increases. With the SEM, the well-crystallized smectites are also seen to be those which present the most distinct authigenic mineral structures (Plate 2). They occur mostly in the brown claystones, whereas the less crystallized varieties are confined to the gray-green mudstones and claystones. An analysis of rare earth elements in well-crystallized forms shows cerium depletion increasing with the iron amount in the beidellites (Fig. $4)$, reflecting sea water influence.

\section{Palygorskites}

Their chemical composition is given in Tables 7 and 8 . With the SEM they show a typically fibrous habit (Plate 2). A clay fraction made of this mineral shows a depletion in cerium (Sample 460-7-1, 108-109 cm). Palygorskites occur in sediments immediately covering the basalts and also in altered basalts (Sample 459B65 , CC 5-6 cm; see Natland and Mahoney, this volume). They do not occur where saponites exist.

\section{DISCUSSION}

The questions raised by the sediments we analyzed concern (1) the sources of the terrigenous material, and (2) diagenesis.

1) If we examine the whole range of mineralogical distributions, we are struck by the absence of minerals such as kaolinite and detrital quartz, which are often found in pelagic and hemipelagic sediments of the oceans (Biscaye, 1965; Griffin et al., 1968; Kolla et al., 1976). On the other hand, calcic plagioclases, pyroxenes, and iron-magnesium silicates abound, whether the last named are from primary origin (talc, chlorite, serpentine) or from secondary origin (palygorskite, saponite). Besides, we note that the mineralogical and chemical differences are small between volcanogenic sediments (tuffs) and associated sediments (mudstones and claystones) as already stated (Chamley and Giroud d'Argood, 1978).
An explanation may be found in the geological setting. Over a period spanning the earlier Pliocene to the late Pleistocene, the Mariana Trough opened and the West Mariana Ridge gradually parted from the Mariana arc to which it previously belonged (see Hussong and Uyeda, this volume). Site 451 revealed that no tuffs were deposited on the West Mariana Ridge since the beginning of the Pliocene, at which time it was submerged (Scott, Kroenke, et al., in press). Since that time, we can look for the sources of the volcanogenic terrigenous material having the trend of "island arc tholeiite series" in the nearest emerged ridge of the trough - that is, in the active volcanic Mariana arc. Previously, during the Miocene, at which time the Parece Vela Basin started to open, terrigenous material could have come from the West Mariana Ridge, which was then emerged and active. It could not have come from the Palau-Kyushu Ridge where volcanic eruptions ceased 30 million years ago, between the early and late Oligocene (Site 448 of Leg 59). On the contrary, during the Eocene, volcanogenic-terrigenous material with a "calc-alkaline" trend may well have come from this ridge.

These speculations are offered with the awareness that volcanic glass, as detected by X-ray diffraction through the amount of amorphous matter in the sediments, besides the biogenic opal CT occurs much more frequently in all lithologies than a rough petrographic examination would reveal.

Finally the differences between tuffs and mudstones are more in grain size than in mineralogy. They are not two types of sediments with components of two specific sources.

The changes in the mineralogical patterns indicate as much the changes in the chemical composition of volcanism (e.g., serpentine) as the impact of erosion and weathering on emerged land (Millot, 1970; Desprairies, 1979). During periods of strong tectonic activity, such as is indicated by the turbidites, erosion is intense and supplies the ocean with primary (talc, chlorite) and moderately altered secondary minerals (mixed layer clays).

During relatively quiet periods of tectonic activity (which correspond to the sedimentation of claystones with a great amount of biogenic silica or carbonates), alteration will progress on emerged islands, with the aforementioned clay minerals giving way to smectites. This is what happened during the late Oligocene. However, the effects of the diagenesis are superimposed upon all these tectonic influences.

2) Diagenesis in the analyzed volcaniclastic sediments seems to derive from two processes:

a) Low-temperature alteration. It affects mostly the volcanic glasses and is more advanced downhole from the Pleistocene to the upper Oligocene. It is characterized by the genesis of pure smectite, the crystallinity and the abundance of which (compared to that of the other clay minerals) improve as the sediment grows older. Probably, the diminution of the grain size and the rate of sedimentation down the sedimentary column (Figs. 2 and 3) are favorable factors, too. The progress 
of submarine alteration is also accompanied by the appearance of zeolites, and, from preliminary analyses, by development of progressively more iron-rich beidellites, and a growing cerium depletion in smectites.

At Hole 459B, as depth increases down to the upper Oligocene, we find gradients in the interstitial water concentration in $\mathrm{Mg}$ and $\mathrm{Ca}$ with depletion of the first element and enrichment of the second (Gieskes and Johnson, this volume). These modifications, which have also been noted often at other DSDP sites, have been attributed to diagenesis by numerous authors (Lawrence et al., 1975; Gieskes et al., 1975; Kastner and Gieskes, 1976; Kastner, 1976). In our opinion, the alteration of volcanic glass, with incorporation of $\mathrm{Mg}$ from interstitial water and release of $\mathrm{Ca}$, are expressed in the genesis of iron-beidellites rich in $\mathrm{Mg}$ (Tables 7 and 8). Saponites are more likely to occur with talc and serpentine. They may derive from the "halmyrolysis,"' but they may also be of detrital origin.

b) High-temperature (hydrothermal) alteration. At the same Hole 459B, throughout 20 meters of Eocene sediments just above the basalts, there is a mass development of authigenic palygorskite in the sediments and also in the altered basalts of the sediments (see also Natland and Mahoney, this volume). At Site 460, palygorskite is the main component of the clay fraction of Eocene sediments $(50 \mathrm{~m})$ above the igneous breccias.

Many opinions have been expressed on the in situ genesis of palygorskite and on the origin of $\mathrm{Mg}$-rich solutions which could have reacted with sea water, glasses, or clay minerals (Bonatti and Joensuu, 1968; Couture, 1977). Palygorskite is not usual in altered basalts (Bass, 1967), nor does it occur in palagonites which normally contain smectites (Honnorez, 1972).

We arrive at the following hypothesis on the genesis of palygorskite:

The enrichment of solutions in $\mathrm{Mg}$ occurs during the hydrothermal alteration of the igneous basement (highmagnesium andesites at Site 459 and island-arc tholeiites at Sites 458 and 459) into a clay minerals/zeolite facies assemblage (Natland and Mahoney, this volume). The minerals which could form in the basalts are chiefly serpentine, chlorite, talc, and smectites (saponite). This process may be deemed to occur later than deposition of the first sediments if the hydrothermal activity is partly due to tectonic causes.

Hydrothermal fluids with a high $\mathrm{Mg} / \mathrm{Ca}$ ratio may react with fresh glasses of the basalt or of the volcaniclastic sediments, or rather with clay minerals, to form palygorskite. It must be noted that the chemical composition of palygorskite is similar to that of iron-beidellites as regards major elements, except magnesium and trace elements. Palygorskite shows the same cerium depletion as beidellites, whereas the saponites sensu stricto that have been analyzed up to now do not show any depletion (Desprairies and Bonnot-Courtois, in press).

\section{CONCLUSIONS}

1. Most of the terrigenous material analyzed is of volcanic origin.
2. The assemblage of detrital clay minerals (talc, chlorite, illite, mixed-layer clays, some smectites) and its modification over the years indicate how alteration and erosion balance each other upon the emerged ridges.

3. Chemical and mineralogical patterns also record the various stages of spreading and evolution of the basins (serpentine, for instance, in Eocene sediments) and the sources of volcaniclastic products.

4. Low-temperature alteration of volcanic matter (mainly glasses) develops with age and depth, but also with some sedimentological features (low rate of sedimentation). The authigenic minerals that appear are pure dioctahedral smectites, the crystallinity of which increases with their iron content, and zeolites (phillipsite, clinoptilolite).

5. Hydrothermal Mg-rich solutions, ascending from igneous basement, seem to be the cause of a massive development of palygorskite in the sediments immediately overlying basalts in Hole 459B and in the altered basalts themselves.

\section{ACKNOWLEDGMENTS}

1 thank the U.S. National Science Foundation, and am grateful to Dr. Rene Blanchet for sampling the sediments for this study. I thank Dr. Chantal Courtois for REE analyses and Dr. Cecile Jehanno, Laboratoire des Faibles Radioactivites de Gif sur Yvette (France), for SEM examination and analyses of zeolites and clay minerals using the EDAX system. Dr. Miriam Kastner and Pierre E. Biscaye read the manuscript and offered helpful suggestions. This research was supported by CNRS, ERA 765, and ATP IPOD contract No. 3767.

\section{REFERENCES}

Alietti, A., 1959. Diffusione e significato dei minerali a strati misti delle serpentine mineralizzate a talco dell' Appennino Parmense. Periodico di Mineralogie, 28:65-110.

Aoki, S., Kohyama, N., and Sudo, T., 1974a. An iron-rich montmorillonite in a sediment core from the northeastern Pacific. Deep Sea Res., 21:865-875.

Aoki, S., Oinuma, K., and Sudo, T., 1974b. The distribution of clay minerals in the Recent sediments of the Japan Sea. Deep Sea Res., 21:299-310.

Bass, M. N., 1976. Secondary minerals in oceanic basalt, with special reference to Leg 34, Deep Sea Drilling Project. In Yeats, R. S., Hart, S. R., et al., Init. Repts. DSDP, 34: Washington (U.S. Govt. Printing Office), 393-432.

Beutelspacher, H., and van der Marel, H. W., 1968. Atlas of Electron Microscopy of Clay Minerals and their Admixtures: New York (Elsevier).

Biscaye, P. E., 1965. Mineralogy and sedimentation of recent deepsea clay in the Atlantic Ocean and adjacent seas and oceans. Geol. Soc. Am. Bull., 76:803-832.

Boles, J. R., 1971. Synthesis of analcime from natural heulandite and clinoptilolite. Am. Mineral., 56:1724-1734.

Bonatti, E., and Joensuu, O., 1968. Palygorskite from the Atlantic deep-sea sediments. Am. Mineral., 53:975-983.

Boström, K., Joensuu, O., Valdes, S., et al., 1972. Geochemical history of South Atlantic Ocean sediments since late Cretaceous. Mar. Geol., 12:85-121.

Brown, G., 1963. The X-ray Identification and Crystal Structures of Clay Minerals: London (Mineralogical Society).

Chamley, H., and Giroud d'Argoud, G., 1978. Clay mineralogy in volcanic sediments. In Hsü, K., Montadert, L., et al., Init. Repts. DSDP, 42, Pt. 1: Washington (U.S. Govt. Printing Office), 395-397.

Courtois, C., and Hoffert, M., 1977. Distribution des terres rares dans les sédiments superficiels du Pacific sud-est. B.S.G.F. (7) 19 (6): 1245-1251.

Couture, R. A., 1977. Composition and origin of palygorskite-rich and montmorillonite-rich zeolite containing sediment from the Pacific Ocean. Chem. Geol., 19:113-130. 
Desprairies, A., 1979. Etude sédimentologique de formations à caractère flysch et molasse, Macédoine, Epire (Grèce). Mem. Soc. Geol. France, 58 (136):1-80.

Dixon, T. H., and Batiza, R., 1979. Petrology and chemistry of recent lavas in the Northern Marianas: Implications for the origin of island arc basalts. Contrib. Mineral. Petrol., 70:167-181.

Fleet, A. J., Henderson, P., and Kempe, D. R. C., 1976. Rare earth elements and related chemistry of some drilled southern Indian Ocean basalts and volcanogenic sediments. J. Geophys. Res., $81: 4257$.

Gieskes, J. M., Kastner, M., and Warner, T. B., 1975. Evidence for extensive diagenesis, Madagascar, Basin, Deep Sea Drilling Site 245. Geochim. Cosmochim. Acta, 39:1385-1393.

Griffin, J. J., Windom, H., and Goldberg, E. D., 1968. The distribution of clay minerals in the World Ocean. Deep Sea Res., 15:433459.

Hein, J. R., and Scholl, D. W., 1977. Diagenesis and distribution of late Cenozoic volcanic sediment in the southern Bering Sea. Geol. Soc. Am. Mem., 88.

Honnorez, J., 1972. La Palagonitisation. Kristallogr. Petrograph. Institut der Eidgenössischen Technischen Hochsule, Zürich, No: 9.

Jakê̂, P., and White, A. J. R., 1972. Major and trace elements abundances in volcanic rocks of orogenic areas. Geol. Soc. Am. Bull., 83:29-40.

Kastner, M., 1976. Diagenesis of basal sediments and basalts of Sites 322 and 323, Leg 35, Bellingshausen Abyssal Plain. In Hollister, C. D., Craddock, C., et al., Init. Repts. DSDP, 35: Washington (U.S. Govt. Printing Office), 513-537.

Kastner, M., and Gieskes, J. M., 1976. Interstitial water profiles and sites of diagenetic reactions, Leg 35, DSDP, Bellinghausen Abyssal Plain. Earth Planet. Sci. Lett., 33:11-20.

Kastner, M., and Stonecipher, S. A., 1978. Zeolites in pelagic sediments of the Atlantic, Pacific and Indian Oceans. In Sand, L. B., and Mumpton, F. A. (Eds.), Natural Zeolites, Occurrence, Properties, Use: New York (Pergamon).

Kohyama, N., Shimoda, S., and Sudo, T., 1973. Iron-rich saponite (ferrous and ferric forms). Clays Clay Miner., 21:229.

Kolla, V., Henderson, L., and Biscaye, P. E., 1976. Clay mineralogy and sedimentation in the western Indian Ocean. Deep Sea Res., 23: 949-961.

Lawrence, J. R., Gieskes, J. M., and Broecker, W. S., 1975. Oxygen isotope and cation composition of DSDP pore waters and the alteration of layer II basalts. Earth Planet. Sci. Lett., 27:1-10.

Melson, W. G., and Thompson, G., 1973. Glassy abyssal basalts, Atlantic Sea Floor near St. Paul's Rocks: Petrography and composition of secondary clay minerals. Geol. Soc. Am. Mem., 84:703716.

Millot, G., 1970. Geology of Clays: New York (Springer).

Miyashiro, A., and Shido, F., 1975. Tholeiitic and calc-alkalic series in relation to the behaviors of titanium, vanadium, chromium and nickel. Am. J. Sci., 275:265-277.

Piper, D. Z., 1974. Rare earth elements in the sedimentary cycle: a summary. Chem. Geol., 14:285.

Reynolds, R. C., and Hower, J., 1970. The nature of interlayering in mixed-layer illite-montmorillonite. Clays Clay Miner., 18:25-36.

Scheidegger, K. F., and Stakes, D. S., 1977. Mineralogy, chemistry and crystallisation sequence of clay minerals in altered tholeiitic basalts from the Peru Trench. Earth Planet. Sci. Lett., 36: 413422 .

Scott, R., and Kroenke, L., in press. In the Philippine Sea, questions answered. Geotimes.

Shipboard Scientific Party, 1978. Leg 60 ends in Guam. Geotimes, October 1978, pp. 19-22.

Weaver, C. E., and Pollard, L. D., 1973. The chemistry of clay minerals. Developments in Sedimentology (Vol. 15): New York (Elsevier). 

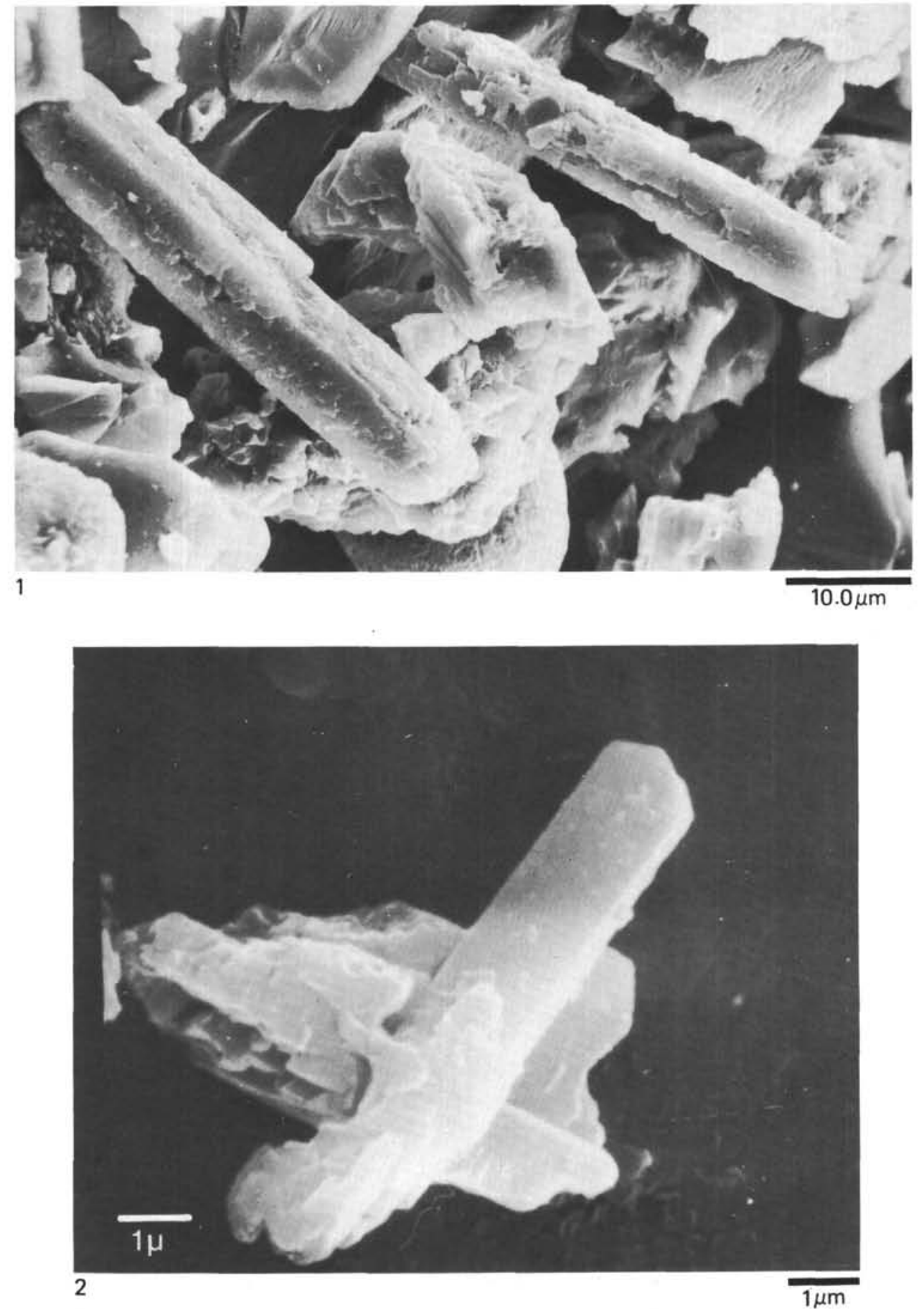

Plate 1. Scanning electron microscope photographs, Hole 459B. For chemical analyses refer to Tables 8 and 9.
Figure 1. Phillipsite-Sample 56-4, 3-4 cm.

Figure 2. Clinoptilolite-Sample 59, CC, 11-12 cm. 

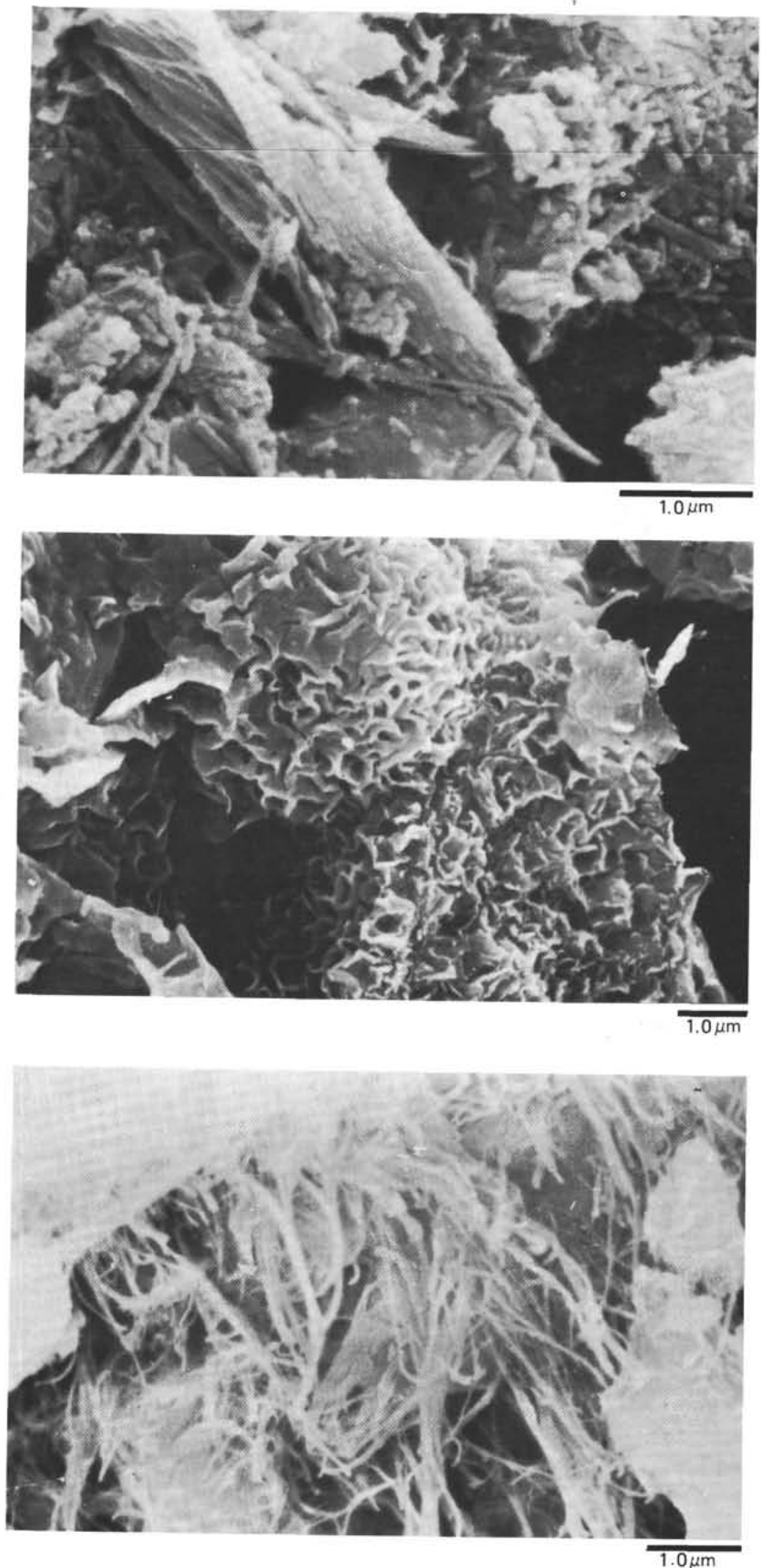

Plate 2. Scanning electron microscope photographs. For chemical analyses refer to Tables 7 and 8 .
Figure 1. Talc-saponite(?). Sample 460A-6-1, 35-36 cm.

Figure 2. Authigenic iron-beidellite-Sample 459B-56-4, 117-119 cm.

Figure 3. Authigenic palygorskite-Sample 460-7-1, 108-109 cm. 